\title{
Efficiency of Pseudomonas fluorescens and Bacillus subtilis against Phytophthora spp. in citrus
}

\author{
S.B. SHINDE* AND M.D. SADGIR
}

Department of Plant Pathology, Post Graduate Institute, Dr. Panjabrao Deshmukh Krishi Vidyapeeth, AKOLA (M.S.) INDIA

\section{ARITCLE INFO}

Received : 22.09 .2015

Revised : 01.02 .2016

Accepted : 15.02 .2016

\section{KEY WORDS :}

Pseudomonas fluorescens, Bacillus subtilis, Phytophthora spp.

*Corresponding author:

Email: shindesb123@gmail.com

\section{ABSTRACT}

Phytophthora was recorded in all the soil samples collected from citrus orchards and nurseries. Out of 25 soil samples Isolates of Pseudomonas fluorescens and Bacillus subtilis recorded from 11 and 5 soil samples, respectively. In vitro, four isolates of Pseudomonas fluorescens and two isolates of Bacillus subtilis were found effective against Phytophthora parasitica and other fungal pathogens of citrus viz., Pythium sp., Fusarium sp. and Colletotrichum gloeosporioides. Efficacy tested under sick soil method, only Bs- $\mathrm{K}_{1}$ (a) isolate of Bacillus subtilis was found most effective giving maximum disease control (81.34\%), while other isolates of Pseudomonas fluorescens and Bacillus subtilis were not found much efficient.

How to view point the article: Shinde, S.B. and Sadgir, M.D. (2016). Efficiency of Pseudomonas fluorescens and Bacillus subtilis against Phytophthora spp. in citrus. Internat. J. Plant Protec., 9(1): $15-20$ 